\title{
Alien Plant Diversity in Mediterranean Wetlands: A Comparative Study within Valencian, Balearic and Sardinian Floras
}

\author{
Olga MAYORAL ${ }^{1 *}$, Francesco MASCIA ${ }^{2}$, Lina PODDA ${ }^{2}$, \\ Emilio LAGUNA ${ }^{3}$, Pere FRAGA ${ }^{4}$, Juan RITA ${ }^{5}$, \\ Luca FRIGAU ${ }^{2}$, Gianluigi BACCHETTA ${ }^{2,6}$ \\ ${ }^{1}$ Universitat de València, Dpt. Didáctica de las Ciencia Experimentales y Sociales, Fac. Magisterio, Avda. Tarongers, 4 46021; Jardí Botànic de \\ la Universitat de València,Valencia, Spain; olga.mayoral@uv.es (*corresponding author) \\ ${ }^{2}$ Università degli Studi di Cagliari, Centro Conservazione Biodiversità (CCB), Dipartimento di Scienze della Vita e dell'Ambiente, v.le S. \\ Ignazio da Laconi 11-13,09123 Cagliari, Italy; hippolais@tiscali.it; lina.podda@gmail.com; luca.frigan@gmail.com \\ ${ }^{3}$ Generalitat Valenciana, Conselleria de Agricultura, Medio Ambiente, Cambio Climático y Desarrollo Rural, Servicio de Vida Silvestre - CIEF. \\ - Avda. Comarques del Pais Valenciä, 114-E. 46930 Quart de Poblet-Valencia, Spain; laguna_emi@gva.es \\ ${ }^{4}$ Institut Menorqui d'Estudis (IME), Secció de Ciències Naturals; Cami des Castell, 28, 07702 Maó, Menorca, Illes Balears, \\ Spain;pere.fraga@gmail.com \\ ${ }^{5}$ Universitat de les Illes Balears, Dpt. Biologia, Cra. Valldemossa, km 7.5. Palma, Illes Balears, Spain; jrita@uib.es \\ ${ }^{6}$ Università degli Studi di Cagliari, Hortus Botanicus Karalitanus (HBK), v.le S. Ignazio da Laconi 9-11, 09123 Cagliari, \\ Italy;bacchet@unica.it
}

\begin{abstract}
Although wetlands provide an important range of environmental, social and economic services, they are increasingly subjected to anthropogenic perturbations, amongst which invasion by alien plants is particularly alarming. This paper focuses on the alien flora of wetlands from three territories belonging to the western Mediterranean area: one continental (Valencian Community) and two insular (Balearic Islands and Sardinia), providing a complete checklist for the three territories and a general comparison. In total, 380 alien taxa from 89 families have been reported, being the Valencian Community the area richer in taxa (312), followed by the Balearic Islands (151) and Sardinia (134). The invasive component includes 77 taxa, of which nine are common to the three territories - and have been recognised as the most invasive ones in Mediterranean islands and six are considered invasive worldwide (Ailanthus altissima, Arundo donax, Cortaderia selloana, Oxalis pes-caprae, Ricinus communis and Eichhornia crassipes). Multiple Correspondence Analysis (MCA) revealed that the three territories do not show statistically relevant differences in relation to the alien species present in wetlands and their characteristics. The information on the characteristics of plants in similar habitats of the same biogeographic region provides a portrait of the current dimensions of the phenomenon in Western Mediterranean wetlands and is especially useful from the management perspective: its predictive value can be applied in establishing a prioritization of control measures of those most invasive species and will help screening new introductions with invasive potential.
\end{abstract}

Keywords: continent; environmental impact; invasions; islands; non-native plants; water

\section{Introduction}

Wetlands perform various valuable ecosystem services: they recycle nutrients, purify water, recharge ground water, and provide habitat for a wide variety of flora and fauna. Simultaneously, these ecosystems are being increasingly subjected to anthropogenic perturbations (Smith et al., 1999). At the global level, aquatic habitats are amongst the environments most threatened by invasion of alien species (Barrett, 1989; Hood and Naiman, 2000; Cronk and Fennessy, 2001; DiTomaso, 2003; Ervin et al., 2006; Wilby, 2007; Strayer, 2010). This susceptibility is caused by the fragility of these ecosystems, which act as vast sponges, with different levels of resilience to alterations (Carpenter and Cottingham, 1997). Disturbances have been related with the success of invasions and aquatic habitats are especially susceptible to biological invasions: flooding is a common 
318

disturbance in wetlands and an important force continuously reshaping these habitats (Leopold et al., 1964).

The percentage of the recorded introductions in wetlands is the highest in the world: Europe 25.1\%, Asia 16.4\%, Africa $14.7 \%$, Oceania $14.7 \%$, South and Central America 14.1\%, Middle east 8.4\%, north America 6.3\% (Genovesi, 2007). During the last decade, problems associated with the spread of certain alien aquatic plant species were found to be increasing in Europe (Hussner, 2009; 2012), where 30\% of alien freshwater animal and plant species negatively influence freshwater ecosystems, and $24 \%$ have an economic impact (Vila et al., 2009). It is estimated that at least 260 species of plants not native to any part of Europe are established in inland waterways (Keller $e t$ al., 2011). Particularly alien aquatic plants show a higher proportion of species causing impacts upon their habitats than terrestrial species (Hood and Naiman, 2000; Vila et al., 2009). The actual susceptibility of European inland waters to invasions is a direct consequence of the rapid growth of transport, trade and tourism (Genovesi, 2007).

The Mediterranean Basin is one of the main biodiversity hotspots in the world and has high sensitivity to biological invasions due to biogeographic, climatic and socioeconomic conditions (Myers et al., 2000; Mittermeier et al., 2005; Gritti et al., 2006). At the same time, southern and western parts of Europe show higher number of alien aquatic plants than northern and eastern parts as a consequence of the longer growing season and mild winter temperatures (Chytrý et al., 2009). Among different habitats, inland wet areas are shown to be among the most invaded environments of the Mediterranean Basin, with around 20\% of alien taxa (Arianoutsou et al., 2010). The vulnerability of these habitats is increased by anthropic pressure and the problem of water in these meridional regions, where the water is scarce in summer and has to be shared among different ecosystems and human exploitations (that frequently vary depending on political decisions), difficulties increased by the effect of accelerated climate change (Gitay et al., 2011).

The phenomenon of biological invasions is better understood on the scale of habitat since it is at this level where many ecological processes take place (competition, inhibition, facilitation, predation, etc.) (Pino et al., 2008). In addition, this scale is where most of the actions of environmental management and conservation of species are applied. There have been plenty of small-scale studies on invasions involving specific taxa on wetlands in different areas of the Mediterranean Basin (e.g. Domènech and Vila, 2008; Bacchetta et al., 2010; Brundu et al., 2012; Constan, 2012; Mayoral et al., 2012). On the other hand, biological traits play a key role in the invasiveness of alien species, and the comparison of these traits is essential when studying alien species.

Nevertheless, information on the degree of invasion of habitats in Europe is very fragmented and heterogeneous, both in quality and geographic scale (Chytrý et al., 2008; Vila et al., 2008). The comparison within areas from the same biogeographic region is considered noteworthy by different authors (Crawley et al., 1996; Gritti et al., 2006; Podda et al., 2010). Previous comparative studies have been focused on general relationships between compatible countries or geographical spots (e.g. islands) (Crawley et al., 1996; Gómez-Serrano and Mayoral, 2003; Podda et al., 2010; 2011; Puddu et al., 2016). However, to our knowledge, no attempt has been made to compare a single habitat type from different areas in the Mediterranean Basin.

The aim of the present study is to compare the alien flora of wetlands of islands vs. continental Mediterranean areas and to analyse the differences in biological traits of invasive species among the regions analysed. This goal is achieved from the analysis of a built checklist of the alien flora within wetlands of three western Mediterranean areas, one continental (Valencian Community) and two insular (Balearic Islands and Sardinia).

\section{Materials and Methods}

\section{Study areas and habitats}

The study areas are located in the western Mediterranean Basin. From a biogeographic approach, the three territories belong to the western Mediterranean subregion of the Mediterranean region (Fig. 1), with many climatic and bioclimatic similarities. The most represented bioclimate in the three territories is the Mediterranean Pluviseasonal-Oceanic (Rivas-Martínez, 2007).

The Valencian Community (Spain) -hereafter VC- is placed on the eastern part of the Iberian Peninsula. It's a long and narrow region of $23,255 \mathrm{~km}^{2}$ and a coastline of $518 \mathrm{~km}$ lying by the Mediterranean Sea, with 44,862 ha of wetlands.

The Balearic Islands (Spain) - hereafter BL - are located facing the Valencian Community, near the eastern coast of the Iberian Peninsula. The archipelago of the BL has a total area of $4,992 \mathrm{~km}^{2}$, and consists of five main islands: Majorca, Minorca, Ibiza, Formentera and Cabrera, and numerous minor islets, with 2,950 ha of wetlands. The perimeter of its coast has a total length of $1,428 \mathrm{~km}$.

Sardinia (Italy) -hereafter SA- is the second largest island in the Mediterranean Sea (after Sicily and before Cyprus), with an area of $24,089 \mathrm{~km}^{2}$, of which $28,500 \mathrm{ha}$ are occupied by wetlands. The coastline, including more than 300 islands and islets, is about $1,995 \mathrm{~km}$ long.

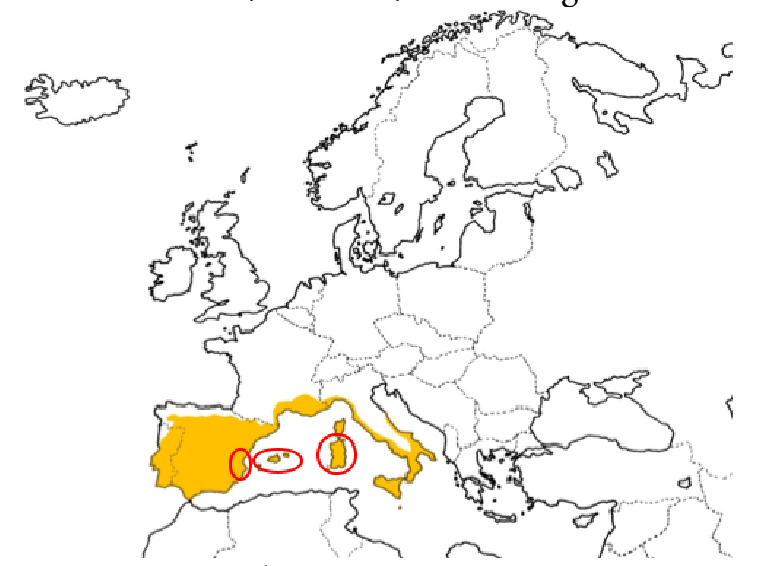

Fig. 1. Study area (ovals from left to right, Valencian Community, Balearic Islands and Sardinia) and limits of the western Mediterranean biogeographic sub-region (yellow) 
Due to their transitional nature and their complex interactions, wetlands are difficult to define and demarcate accurately. In this study the term wetland is considered heterogeneous habitats, as defined in the article 1.1 of the Convention on Wetlands of International Importance (RAMSAR, 1971), including lakes and rivers, swamps and marshes, wet grasslands and peatlands and human-made sites such as ponds, rice paddies, reservoirs, and saltpans. This transitional space between land and water includes numerous and various ecosystems, characterised by an important diversity in structure and hydro-ecological functioning, with permanent or temporary, flowing or static water, including riverbeds, which in Mediterranean areas are dry great part of the year.

\section{Origin of data}

In order to collect data on alien plants of each area, the herbarium material available was consulted and implemented by unpublished data derived from our field investigations carried out during the last ten years. Furthermore, the most important bibliographic data and databases were consulted. In particular, DAISIE database (2017), and for the VC, Gómez-Serrano and Mayoral (2001) and Sanz-Elorza et al. (2011), for the BL, Vila and Muñoz (1999) and Moragues and Rita (2005), and for SA, Bacchetta et al. (2008; 2009b) and Podda et al. (2010; 2011; 2012).

The basis for the present study was a checklist including all the alien taxa found in wetlands of the three territories (Annex I). From a nomenclatural point of view and for the attribution of the taxa to the plant families, the on-line databases of The Plant List website (2010) and of the MedChecklist website (Euro+Med, 2006-onwards) were followed. Concerning the validity of the plant families it was followed what is reported in the Angiosperm Phylogeny Group III (Chase and Reveal, 2009; Stevens, 2001onwards) while for gymnosperms and pteridophytes the works of Christenhusz et al. (2011a, 2011b). Apart from Castroviejo S et al. (eds.) (1986-2017), when available, dedicated taxonomic revisions have been taken into account.

\section{Data treatment and surveying methods}

Invasive taxa were determined and ordered following the scheme proposed by Richardson et al. (2000), elaborated by Pysek et al. (2004) and reviewed according to Richardson et al. (2011).

Archaeophyte and neophyte taxa were differentiated depending on their introduction before or after 1492/1500. This variable was called "residence status". Since it is still a matter of debate if some species can be considered native or not and, in this latter case, if they are archaeophytes or neophytes (Carlton, 1996; Celesti-Grapow et al., 2010), for these taxa for which such doubts still persist, we have preferred the attribution of doubtful (D). In order to differentiate the presence (as native) from the absence, those taxa present as alien in the whole territory (but not in wetlands) were stated as PA and those present as natives were stated as PN. This information is included in the checklist of Annex I but was not used for the analysis.
Life forms for taxa were determined following the classification of Raunkiaer (1934) and using the abbreviations of Pignatti (1982).

Species origin is based on geographical area or biogeographical region according to Sanz-Elorza et al. (2011), Moragues and Rita (2005) and Bacchetta et al. (2009a).

Taxa were also classified according to their intentional or not intentional anthropogenic introduction, following the considerations of the guiding principles of the Convention on Biological Diversity (CBD) and the European Strategy on Invasive Alien Species (European IAS Strategy) (Miller et al. 2006). Regarding introduction pathways, the categories proposed by Sanz-Elorza et al. (2004) and Hulme et al. (2008) were modified and adapted. Cultivated, ornamental or forestry taxa that do not show any degree of naturalization have not been taken into account in the present work.

Moreover, the impact of each invasive taxon was examined according to Celesti-Grapow et al. (2010) readapted with the identification of three broad categories according to Podda et al. (2011): (1) Environmental (competition and hybridisation; changes in the structure and function of the habitats; abiotic changes); (2) Economic (agricultural weeds; threatening livestock; damaging human constructions, infrastructures, monuments and archaeological remains); (3) Human health (toxic; poisonous; allergenic and armed species). The assignment of impact classes to each taxon was made at regional level and based on field data and expert-based knowledge.

\section{Data analysis}

In order to analyse the relationship among the three territories (VC, BL and SA) we used the Multiple Correspondence Analysis (hereafter MCA) (Benzécri, 1979). The initial matrix for the MCA was composed of 597 rows and 14 variables. Each row represents a taxon present in a specific territory. The considered variables are: Territory (VC, BL, and SA), Name of taxa, Type (residence status: archaeophyte and neophyte), Life form (Ph, Th, Ge, $\mathrm{He}, \mathrm{Hy}$ and $\mathrm{Ch}$ ), Taxa origin (Africa, America, Asia, Australia, South Africa, Euroasia, Europe, Mediterranean and Saharo-Arabian, Others), Status (naturalised, invasive, casual), Introduction pathways ornamental (Yes or Not), Introduction pathways agriculture (Yes or Not), Introduction pathways forestry (Yes or Not), Introduction pathways seed contaminant (Yes or Not), Introduction pathways hitchhikers (Yes or Not), Environmental impact (Yes or Not), Economic impact (Yes or Not) and Health impact (Yes or Not).

Through MCA we defined a pattern of relationships of twelve categorical variables (all those listed above except Territory and Name of taxa), describing the features that taxa can assume in a territory. We projected Territory and Name of taxa as supplementary variables on the pattern in order to analyse their positioning.

Furthermore, T-test and Chi-square test were used to analyse the dependence across all variables by twos. All analyses were performed using SPAD 7.4 software. 


\section{Results}

A total of 380 alien taxa were recorded in the wetlands of the entire study area, distributed in 89 families and 169 genera (Annex I). Alien plants of wetlands represent the $47.1 \%$ (312 taxa) of the whole alien flora of the VC, the $42.8 \%$ (151) of the BL, and the $29.3 \%$ (134) of SA.

The highest percentages of alien taxa by families correspond to Poaceae (49 taxa, 12.9\%), Asteraceae (35, $9.2 \%)$ and Fabaceae $(31,8.2 \%)$ for the territory studied as a whole. With regard to the study of families by territories, the alien flora of the VC includes 82 families, 57 the $\mathrm{BL}$ and 53 SA (Fig. 2).

Neophytes and archaeophytes are $77.6 \%$ (295 taxa) and $20.5 \%$ (78 taxa) of the total and seven taxa are stated as doubtful. The proportion of neophytes is of $82.4 \%$ (257 taxa) for the VC, $82.1 \%$ (124) for the BL and $73.1 \%$ (98) for SA, and of archaeophytes is of $17.6 \%$ (55) for the VC, $17.9 \%$ (27) for the BL and $26.9 \%$ (36) for SA. The invasive component represents the $17.9 \%$ for the VC (56 taxa, of which 51 are neophytes and five archaeophytes), 23.2\% for the BL (35 taxa, 32 neophytes and three archaeophytes) and $18 \%$ for SA (23 taxa, 19 neophytes and four archaeophytes).

Neophytes are mainly represented by invasive and naturalised taxa; only in Valencian wetlands casual species are dominant within the neophytes (Fig. 3). Among the 78 archaeophytes detected, only two (Arundo donax and Ricinus communis) are invasive in the three territories and four in some of them (Acanthus mollis subsp. mollis, Sorghum halepense, Spartium junceum and Ulmus pumila)

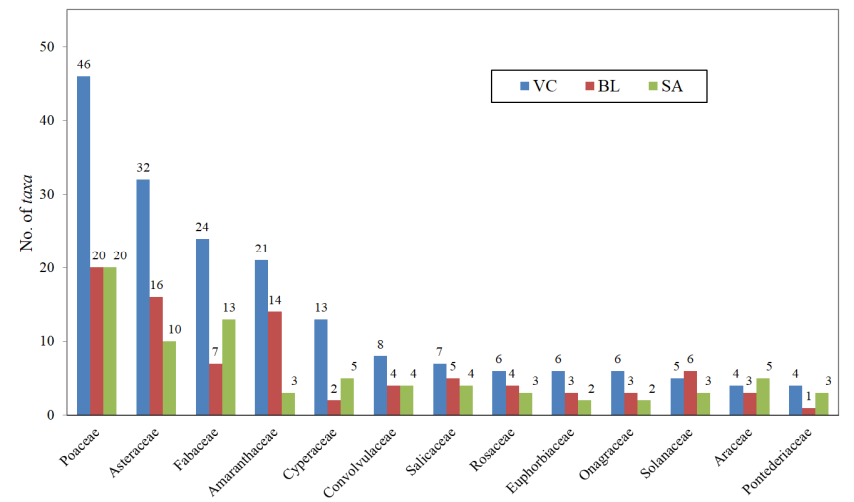

Fig. 2. Comparison of the number of taxa per family in each of the three territories

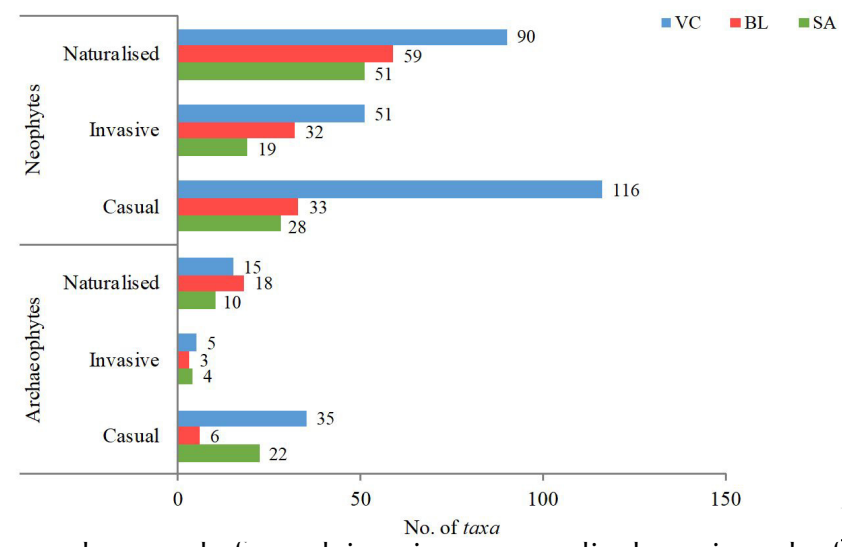

neophytes and of casual, invasive or naturalised taxa in each of the three territories while 31 are naturalised in at least one of the three study areas. Remaining taxa (42) are casual or doubtful.

Invasive component comprehends 77 taxa, 56 are invasive in the VC, 35 in the BL and 23 in SA, among which only nine (Ailanthus altissima, Arundo donax, Cortaderia selloana, Oxalis pes-caprae, Symphyotrichum squamatum, Cyperus involucratus, $R$. communis, Mirabilis jalapa, Eichhornia crassipes) are common to the three regions, while 30 have invasive behaviour exclusively in the wetlands of the VC, 15 only in the BL, and four only in SA (see Annex I).

Naturalised taxa represent $33.7 \%$ for the VC (105 taxa), $51 \%$ for the BL (77), and $45.5 \%$ for SA (61), while $48.6 \%$ (151) represent the casual element in the VC, $21 \%$ (18) in the BL $25.8 \%$ (39) and $37.3 \%(50)$ in SA.

The comparison of the biological spectrum from the three territories reveals that the best represented plants are the ones that occupy the extremes in terms of duration of their life cycle, size and degree of lignification: phanerophytes are the most represented (33.4\%, 127 taxa), followed by therophytes $(27.1 \%, 103)$, geophytes $(15.8 \%$, $60)$, hemicryptophytes $(13.9 \%, 53)$ and hydrophytes $(18$, $4,7 \%)$. Chamaephyte is the least represented life form, with 15 taxa (3.9\%). Furthermore, the comparison of life forms (Fig. 4) individually for each territory reveals that phanerophytes are the most represented for the VC (31.4\%), the BL (38.4\%) and SA (34.3\%) followed by therophytes (29.5\% VC, $27.8 \%$ BL, 26.1\% SA). Hydrophytes have the highest percentage in SA (4.5\% VC, $1.3 \% \mathrm{BL}, 7.5 \% \mathrm{SA})$, while chamaephytes in the $\mathrm{BL}(3.2 \%$ VC, $6.6 \% \mathrm{BL}, 1.5 \% \mathrm{SA})$. On the other hand, geophytes account in wetlands of the VC a $17.3 \%, 15.9 \%$ in the BL and $17.2 \%$ in SA.

The proportion of invasive/alien taxa within each life form is higher for hydrophytes (33.3\%, six taxa), followed by geophytes $(28.3 \%, 17)$, therophytes $(23.3 \%, 24)$, hemicryptophytes $(22.6 \%, 12)$, chamaephytes $(13.3 \%$, two and phanerophytes $(10.2 \%, 13)$. In relation to the levels of significance, the proportion of hydrophytes in the invasive spectrum was higher respect to the total of taxa $(p<0.015)$, while for phanerophytes the higher proportion belonged to casual taxa $(\mathrm{p}<0.001)$.

Regarding the geographical origin, the dominance of the American element (144 taxa, 37.9\%), both in total and for each territory ( $40.4 \% \mathrm{VC}, 43.7 \% \mathrm{BL}, 41.8 \% \mathrm{SA})$ is revealed,

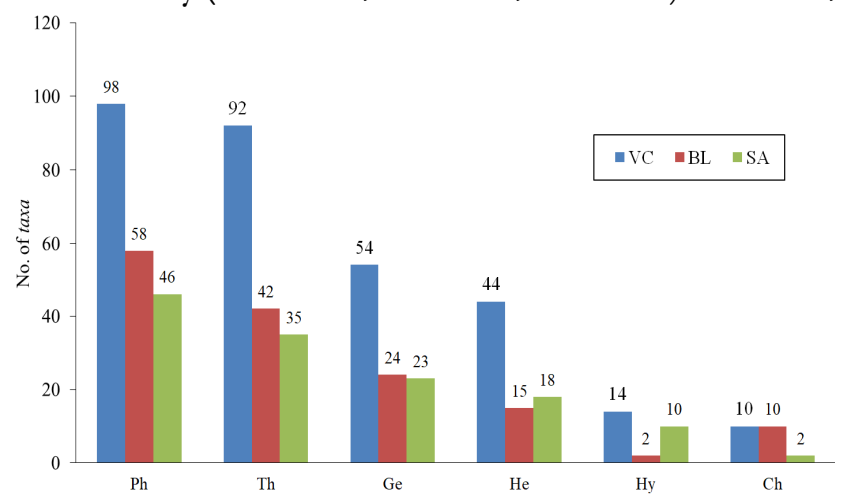

Fig. 4. Comparison of the number of taxa depending on life forms, for each of the study areas. Ph: phanerophyte, Th: therophyte, Ge: geophyte, He: hemicryptophyte, Hy: hydrophyte, Ch: chamaephyte 
followed by the Asian origin ( 55 taxa, 14.5\%; 16.7\% VC, 9.9\% BL, $13.4 \% \mathrm{SA}$ ), the Mediterranean (50 taxa, 13.2\%; $11.9 \% \mathrm{VC}, 13.9 \% \mathrm{BL}, 10.4 \% \mathrm{SA})$ and the African (20 taxa, 5.3\%; 5.1\% VC; $11.3 \%$ BL, 4.5\% SA) (Fig. 5). Among the American taxa, the proportion of invasive plants is higher than for all the taxa $(\mathrm{p}<0.001)$. It was also found that among American plants, both the proportion of hydrophytes $(p<0.001)$ and that of therophytes $(p<0.012)$ was higher than the others. The proportion of the African element in the BL was higher than in the other areas ( $p$ $<0.008)$.

The data analysis of introduction pathways reveals that in all territories human beings introduced a great part of taxa intentionally (48.2\% VC, 54.9\% BL, 65.7\% SA), being ornamental use the main purpose of introductions. Unintentional causes represented by the accidental introduction (hitchhikers) are the second most important pathway for the VC (27.9\%) and for the BL (18.1\%) while in SA, introductions promoted by seeds contamination are more frequent $(23.8 \%)$. Plants intentionally introduced by agriculture show similar low percentages, while forestry represents the least frequent introduction pathway (Fig. 6). The proportion of hitchhikers is higher in the VC than in the rest of territories $(p<0.001)$. Moreover, among the invasive taxa, the proportion of hitchhikers is also higher than in the rest of status $(\mathrm{p}<0.003)$.

The analysis of the negative consequences caused by invasive plants in wetlands shows that most of them

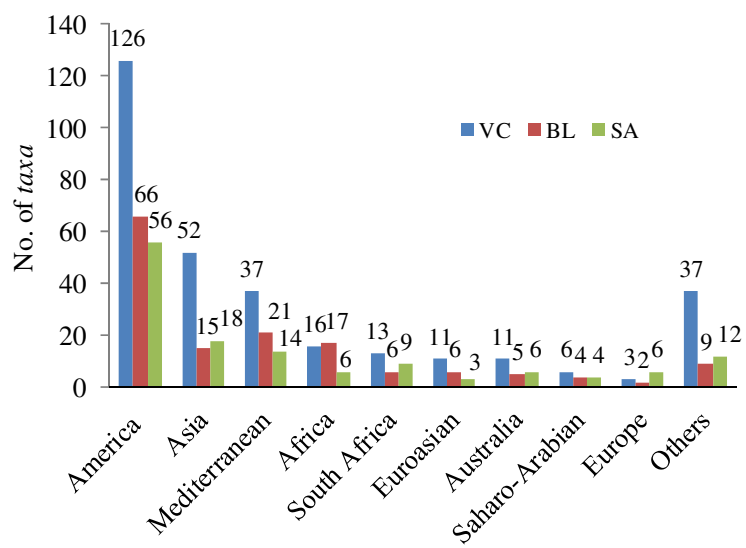

Fig. 5. Comparison of the number of taxa, depending on their geographical origin

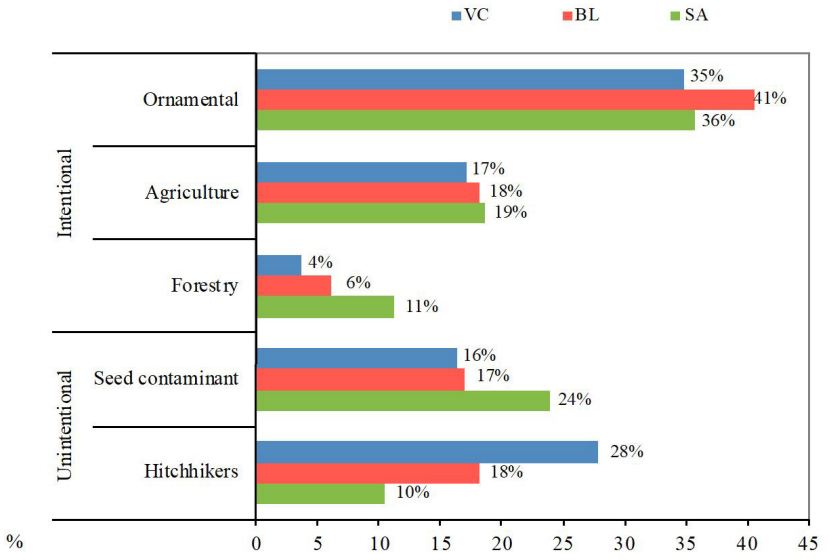

Fig. 6. Distribution of alien plants in the study areas in relation to the introduction pathways (intentional or unintentional) generally produce an environmental (58.9\% VC, 60.3\% BL, $44.2 \%$ SA) and economic (26.3\% VC, 32.8\% BL, 36.5\% SA) impact. Human health is minimally affected $(14.7 \%$ VC, $6.9 \%$ BL, 19.2\% SA) (Fig. 7). The environmental impact is higher in the BL than in the other territories ( $p$ $<0.001$ ). Regarding the impact on health, it is higher in hydrophytes than in other biological forms ( $p<0.001)$, while in geophytes this proportion is higher in relation to the economic impact $(\mathrm{p}<0.015)$.

The MCA analysis (Table 1) shows that the first two factors of the pattern explain $23.80 \%$ of the inertia (i.e. variance of data). But applying Benzécri's (1979) correction formula for MCA -that amends the underestimation of the first dimension and defines the correct percentage of variance explained-, the first two factors explain $85.56 \%$ of the total variance. The graphical output has been represented in Fig. 8. Since all active variables that built the model have coordinates different from zero $(p<0.05)$ at least for one of the two factors, we can state that all of them contributed to the model building. As the coordinates of the three modalities of the Territory variable cannot be considered as different from zero, they are not influenced by the two factors and consequently none can be considered as associated to any active modality or variable. In other words, the three territories (VC, BL and SA) do not present any statistically relevant difference taking into account those active modalities.

\section{Discussion}

The results of this study improve the knowledge of the alien flora of the wetlands from three territories belonging to the western Mediterranean area.

\section{Habitats}

One of the most striking aspects of the results of this study is that about half of the alien taxa found in wetlands

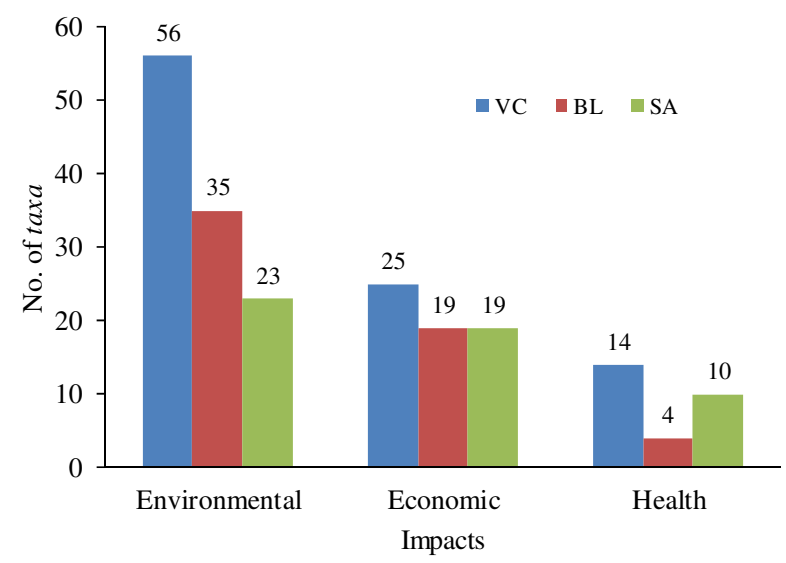

Fig. 7. Distribution of invasive alien plant species in the study areas in relation to the impacts they cause

Table 1. Inertia explained by the first five factors

\begin{tabular}{cccccc}
\hline Factors & F1 & F2 & F3 & F4 & F5 \\
\hline Inertia (\%) & 13.55 & 10.25 & 8.27 & 5.93 & 4.99 \\
\% Accumulated inertia & 13.55 & 23.80 & 32.07 & 38.00 & 42.99 \\
& After Benzécri's correction & & \\
Inertia (\%) & 60.23 & 25.43 & 11.50 & 2.12 & 0.47 \\
\% Accumulated inertia & 60.23 & 85.56 & 97.07 & 99.18 & 99.65 \\
\hline
\end{tabular}


322
F2

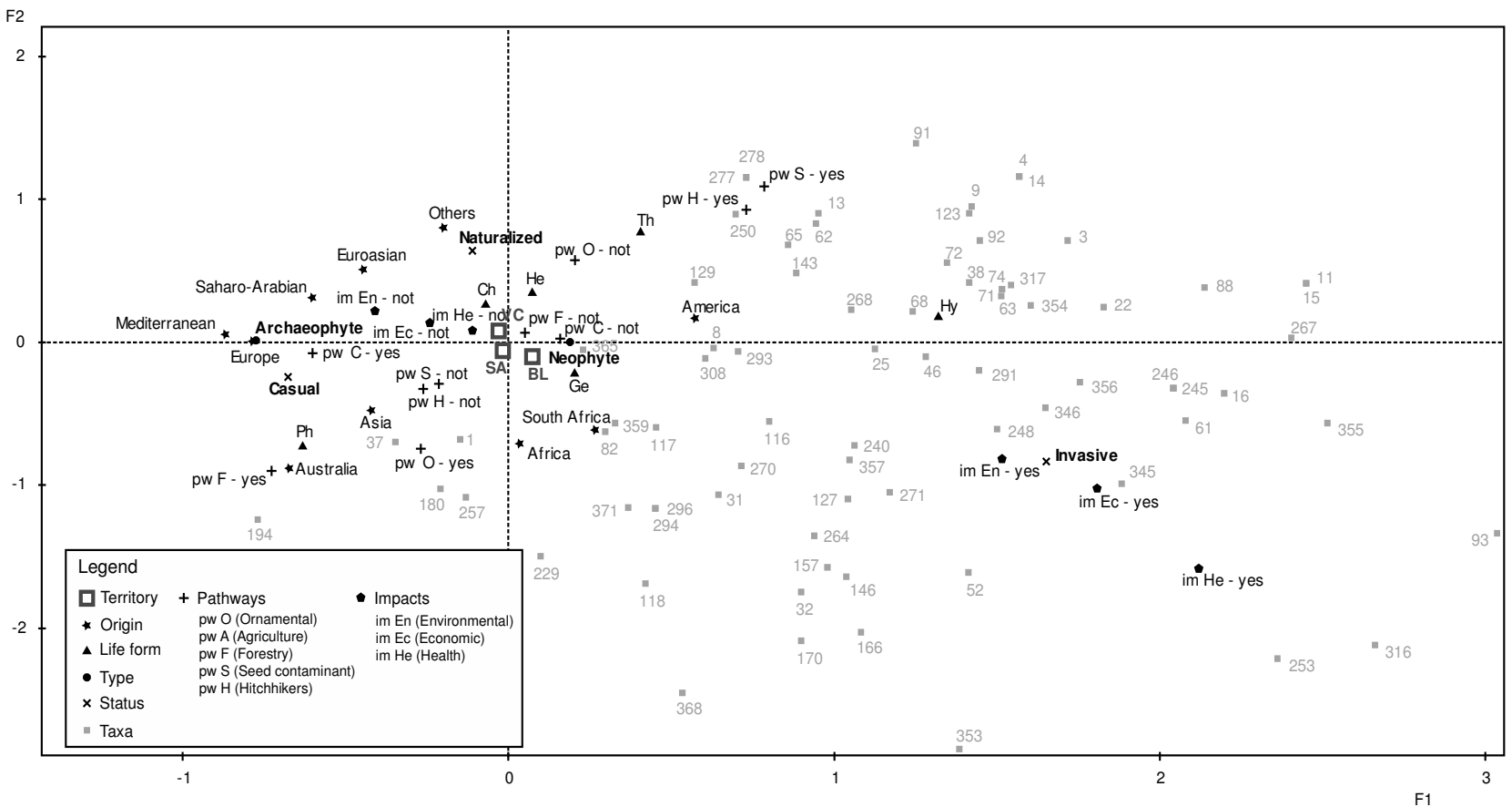

Fig. 8. Map of the MCA where categories are displayed on the first two axes (F1 and F2)

are from terrestrial habitats. Nevertheless, they inhabit ecosystems that are not a priori propitious to them, taking advantage of the seasonality of the presence of water in many Mediterranean wetlands or small spaces with acceptable conditions for their installation. This circumstance has to be taken into account since the evolution of many wetlands -as a consequence of changes in land uses- promotes the drainage and drying of portions and even entire wetlands. This is in synergy with the increase of the periods of drought as a consequence of the accelerated climatic change (Meehl and Tebali, 2004). If this trend of change in land use and climate change remains active, terrestrial alien plants (which appear sporadically and tangentially in wetlands) will increase their surface and become environmental problems of the first order in wetlands.

\section{Islands versus mainland}

Although it has been demonstrated that islands are invaded more frequently than the mainland (Lonsdale, 1999; Daehler, 2006), our data are not conclusive in this regard. While the mainland (VC) is the richest in absolute values, the $\mathrm{BL}$ have a relative richness (relative to the surface in wet areas) much higher than the other two zones. In contrast, SA is the territory with a lower degree of invasion in both absolute and relative terms. Thus, our results suggest that the BL are particularly affected by the problem of alien species in wetlands, but it is on the mainland (VC) where more exotic species arrive and establish.

\section{Plant families}

Concerning families, the presence of Cyperaceae, Salicaceae, Onagraceae and Pontederiaceae within the richest (considered apart from Poaceae, Asteraceae and Fabaceae, which are typically most represented in the Mediterranean context) (Sanz-Elorza et al., 2004), reveals that the exotic flora of wetlands in the western Mediterranean context is largely represented by specialised taxa of wet ecosystems. Poaceae are mostly represented by therophytic and hemicryptophytic weeds that colonise temporary flooded areas (e.g. temporary ponds, riverbeds), while Fabaceae almost completely include phanerophytes that occupy riparian habitats (Aguiar and Ferreira, 2013).

\section{Neophytes versus archaeophytes}

Major differences within the three territories were found in the neophyte component, while differences in archaeophytes were minimal. These results agree with those obtained in some recent comparative studies within the total and invasive floras of the BL and SA (Podda et al., 2010; 2011). Moreover, with the exception of some taxa from Cyperaceae (Cyperus glaber, C. michelianus, Schoenoplectus mucronatus) and $A$. donax, alien taxa introduced before 1492/1500 detected in the wetlands of the study area are ubiquitous and adapted to occupy a wide range of habitats.

\section{Invasive taxa}

Among the nine taxa that show invasive status in all territories, six of them are considered invasive worldwide (A. altissima, A. donax, C. selloana, O. pes-caprae, $R$. communis, E. crassipes) (CABI, 2013) and three in Europe (A. altissima, C. selloana, O. pes-caprae) (DAISIE, 2014) while all taxa (included S. squamatum) have been recognised as the most invasive ones in Mediterranean islands (Lloret $e t$ al., 2004; Hulme et al., 2008).

\section{Life forms}

The comparison of life form data from wetlands with those of the whole alien flora shows very similar data for the three territories. The highest percentages in all territories are 
obtained by phanerophytes, results that broadly agree with those observed in other Mediterranean alien floras, where introduction pathways are mostly intentional, showing the ornamental introductions for gardening superiority over the rest (Gómez-Serrano and Mayoral, 2003; Sanz-Elorza et al., 2004; Podda et al., 2010; Sanz-Elorza et al., 2011). It is found that for the whole of the alien flora of the VC, phanerophytes represent $37 \%$ of the total and therophytes 24\% (Sanz-Elorza et al., 2011) and for SA, phanerophytes $40 \%$, and therophytes $30 \%$, while for the BL, therophytes are more frequent (34\%), followed closely by phanerophytes (32\%) (Podda et al., 2010). The slightly lower percentages of phanerophytes and therophytes for wetlands in comparison with the whole alien flora can be explained by the particularly noteworthy higher percentage of hydrophytes in wetlands in the studied territories.

Hydrophytes are represented by few taxa, although the proportion in wetlands is higher than when considering all the alien taxa of the territories. In addition, hydrophytes show a higher percentage between invasive species than the other life forms. And most important of all is the fact that $1 / 3$ of them are invasive in almost one of the study areas and are evaluated as noxious for species and ecosystems worldwide: Azolla filiculoides, E. crassipes, Hydrocotyle ranunculoides, Lemna minuta, Heteranthera limosa and Salvinia genus resulted the most spread invasive hydrophytic taxa. Egeria densa, Vallisneria spiralis, Lemna paucicostata, $L$. valdiviana and other taxa from Heteranthera genus, are present in almost one site and, due to their noticeable capacity to naturalise, found also in other areas, also of Mediterranean climate. From our point of view, the monitoring of casual/naturalised populations of the hydrophytes is of high priority, as the great number of imported aquatic plant species into Europe continues to be an on-going threat for European freshwater ecosystems (Hussner, 2009).

Many woody plants have been recognised as major invasive species with serious impacts on diversity and functioning of invaded ecosystems (e.g. Richardson, 1998; Pysek et al., 2014; Richardson et al., 2014). In this sense, it has to be taken into account the significant occurrence of bushy and woody species in western Mediterranean wetlands, justified in part by the high susceptibility of riverine habitats to biological invasions (Vila et al., 2008; Costa et al., 2011; Aguiar and Ferreira, 2013). Actually, all phanerophytic species detected in the three study areas specifically occur in riparian ecosystems. Nevertheless, barely 23 taxa (20\%) are typical riparian species (Nerium oleander, Elaeagnus angustifolia, and Alnus, Populus, Salix, Tamarix, Vitis genus) occurring in riverine habitats only, while all remaining taxa are ubiquitous that occur in a great variety of habitats. In fact, phanerophytic species behaving as invasive are $A$. altissima, Asclepias fruticosa, Lantana camara, Lonicera japonica, Pittosporum tobira and $R$. communis, that inhabit a wide range of environments and have been evaluated as the most invasive species (Weber, 2003).

The low occurrence of invasive therophytes is justified by the specialization of this biological form in arid environments (Sarris and Coutsias, 2014): wet habitats are not favourable for annual terrestrial species that are not adapted to resist tide fluctuations, flooding phenomena and asphyxiated soils. For the same reason, in the study area almost all therophytic species invade seasonally dry wetlands as astatic lagoons and temporary ponds, and the dry bed and riverbanks of intermittently flowing streams and rivers (e.g. Amaranthus, Bidens, Chenopodium, Datura, Xanthium genus).

\section{Comparison among territories}

It should be noted that some of the species included in the checklist are not usually mentioned in wetlands but have been found in at least one of the three territories (e.g. Cupressus sempervirens in the $\mathrm{BL}$ as naturalised, Castanea sativa in the VC and SA as casual, Ligustrum lucidum in the VC and the BL as naturalised, Poncirus trifoliata in the VC as casual). The ecological niche shift of these and other taxa should be followed carefully in order to monitor changes in the coming years.

Some species present on the island wetlands are also living in the VC lands, but only recorded as invaders for dry ecosystems (e.g. Antirrbinum majus or Prunus dulcis, herein only referred for the BL, or Senecio inaequidens, reported for SA). Additionally, some of the species reported for one or both islands but absent as wetland invaders in the VC, really match the condition of being native to the continent, e.g. Acer campestre, Rubus idaeus, Trachelium caeruleum, Glinus lotoides, N. oleander, Corylus avellana, etc.

On the other hand, the trend of the VC to hold herbaceous neophytes, often not shared by the $\mathrm{BL}$ and/or SA, could also come from its higher interconnection with other mainland territories, which act as source of new invasive plant species. The VC is connected by roads and train with the remainder European regions, and simultaneously acts as a major industrial and commercial node in Spain -Valencia city is the third main city of Spain-, mainly for agriculture and horticulture, so its availability to receive and host new weeds is really relevant, if compared with the other two territories here analysed. A good example could be given with Diospyros lotus, an aggressive invader of the Valencian wetlands, absent in SA and the BL. The main reason for its presence in the $\mathrm{VC}$ is that it was used during decades for grafting the Persimmon tree (Diospyros kaki), one of the main agricultural productions at local level. D. lotus sprouts from roots after the abandonment of persimmon crops, producing small fleshy fruits which host small seeds dispersed by birds (SENB-CIEF, 2011). Future studies could include the parameter "interconnection of the territory" to help explain the behaviour of alien taxa in different territories.

Despite the two reasons explained above, no absolute rules can be found, and lots of exceptions impede the establishment of clear territorial or behavioural groups in the graphics. Some of these exceptions can be apparently explained by external reasons, such as the degree of competitiveness and the invasion speed of each taxon, the local horticulturist preferences, etc. For instance, the presence of species in SA which are absent in the BL or the VC, such as Phacelia tanacetifolia or Dactyloctenium aegyptium, only represents an early invasion in that territory, for two species which could easily invade the other two territories within a few years (Laguna et al., 2009). The lack of some very aggressive invaders in a concrete territory - e.g. 
324

Ludwigia grandiflora for SA, Salvinia molesta for BL, etc. - is only a question of hazard and time.

\section{Introduction pathways}

Regarding introduction pathways, ornamental use is the main cause of introduction, based on the use of plants from areas with similar climates (Hulme et al., 2008). Furthermore, ornamental trade is considered as the major pathway of aquatic plant introduction within the different continents and climatic regions and thus into Europe (Brunel, 2009; Hussner, 2009). It should also be noted that introductions promoted by agriculture or unintentional introduction of seeds as contaminants are more frequent in $\mathrm{SA}$ than in the VC and the BL.

\section{Impact}

In the three territories, all invasive plants may cause impact on the environment because of fierce competition with native species, often causing their disappearance and modifying the function and structure of their habitats. The six invasive species common in the three territories, which are a threat not only for the environment, but also for economic activities and human health are $A$. donax, $C$. selloana, $R$. communis, A. altissima, $O$. pes-caprae and $E$. crassipes, considered also invasive worldwide (CABI 2013). Among the exclusively aquatic species such as $E$. crassipes (VC, BL and SA), A. filiculoides (VC and SA), $L$. grandiflora (VC and $\mathrm{BL})$, Ludwigia repens and $H$. limosa (BL), it should be emphasised that the impact is also socioeconomic (Sala et al., 2000; Genovesi, 2007). In addition, the study showed that health impact by hydrophytes is higher than by other biological forms, which emphasises the danger of these species.

The information compiled on the invasive plants present in the wetlands of the western Mediterranean provides a snapshot of the current dimensions of the phenomenon and will be useful for managers, in order to prevent the introduction of species that are considered invasive in similar regions. From the management perspective, the predictive value of the floristic researches that enable information sharing is essential and will be of special value when little information is available on the invader's characteristics, arrival date or spatial extent. Before control or eradication alternatives can be considered, information on the behaviour of some species in similar habitats of the same biogeographic region will prove especially useful (Sanz-Elorza et al., 2004; Keller and Perrings, 2011; Hussner, 2012; Aguiar and Ferreira, 2013).

\section{Conclusions}

The comparative analyses presented in this paper shows the similarities and differences in wetlands alien plant diversity between three areas from western Mediterranean, one continental (Valencian Community - Spain -) and two insular (Balearic Islands - Spain - and Sardinia - Italy -). An updated checklist is provided and detailed statistical analyses provide results and conclusions especially useful for management of wetlands and of certain alien species, outlying those with invasive behaviour.

\section{Acknowledgements}

Authors want to thank Provincia di Cagliari for financing part of the research activity. This research received a RAS research grant cofinanced by POR Sardegna FSE 2007-2013 L.R.7/2007 "Promozione della ricerca scientifica e dell'innovazione tecnologica in Sardegna". The project is also part of the research project "Censimento, monitoraggio, controllo e/o eradicazione di specie alloctone vegetali nel Parco Naturale nel Parco Naturale Regionale Molentargius-Saline", financed by the Parco Naturale Regionale Molentargius-Saline.

\section{References}

Aguiar FCF, Ferreira MT (2013). Plant invasions in the rivers of the Iberian Peninsula, south-western Europe: A review. Plant Biosystems 147:11071119.

Arianoutsou M, Delipetrou P, Celesti-Grapow L, Basnou, C, Bazos I, Kokkoris Y, Blasi C, Vila M (2010). Comparing naturalized alien plants and recipient habitats across an east-west gradient in the Mediterranean Basin.Journal of Biogeography 37:1811-1823.

Bacchetta G, Mascia F, Mayoral O, Podda L (2008). Dati preliminari sulla flora aliena delle aree umide della Sardegna (Italia) [Preliminary data on the alien flora of wetlands of Sardinia (Italy)]. Memorie Società Italiana Scienze Naturalie Museo Civico Storia Naturaledi Milano 36:41.

Bacchetta G, Mayoral O, Podda L (2009a). Catálogo de la flora exótica de Cerdeña (Italia) [Checklist of the alien flora of Sardinia (Italy)]. Flora Montiberica41:35-61.

Bacchetta G, Dettori CA, Donat-Torres MP, Mascia F, Mayoral O, Podda L, Silveyra R (2009b). Comparación de la flora vascular exótica de zonas húmedas de la Comunidad Valenciana (España) y Cerdeña (Italia) [Comparison of the alien vascular flora of wetlands of the Valencian Community (Spain) and Sardinia (Italy)]. "EEI 2009" III Congreso Nacional sobre Especies Exóticas Invasoras. (2427 November, Zaragoza,Spain).42 Ed GEI León, Spain.

Bacchetta G, Dettori CA, Mascia F, Meloni F, Podda L (2010). Assessing the potential invasiveness of Cortaderia selloona in Sardinian wetlands through seed germination study. Plant Biosystems 144:518-527.

BarrettSCH (1989). Waterweed invasions. Scientific American 261:90-97.

Benzécri JP (1979). Sur le calcul des taux dinertie dans lanalyse d’un questionnaire [On the calculation of the rates of inertia in the analysis of aquestionnaire]. Cahiers del'Analyse des Données 4:377-378.

Brundu G, Stinca A, Angius L, Bonanomi G, Celesti-Grapow L, D'Auria G, Griffo R, Migliozzi A, Motti R, Spigno P (2012). Pistia stratiotes L. and Eichbornia crassipes (Mart.) Solms: emerging invasive alien hydrophytes in Campania and Sardinia(Italy).EPPO Bulletin 42:568-579.

Brunel S (2009). Pathway analysis: aquatic plants imported in 10 EPPO countries. EPPO Bulletin 39:201-213.

CABI (2016). Invasive Species Compendium. Wallingford, UK: CAB International. Retrieved 2017 January 02 from www.cabi.org/isc.

Carlton JT (1996). Biological invasions and cryptogenic species. Ecology 77:1653-1655.

Carpenter SR, Cottingham KL (1997). Resilience and restoration of lakes. Conservation Ecology 1:2.http://www.consecol.org/vol1/iss1/art2/. 
Castroviejo S et al. (Eds) (1986-2017). Flora iberica. Real Jardín Botánico Madrid. CSIC.Madrid.

Celesti-Grapow L, Pretto F, Carli E, Blasi C (Eds) (2010). Non-native and invasive vascular flora of the regions of Italy. Casa Editrice. Università La Sapienza, Roma, Italy.

Chase MW, Reveal JL (2009). A phylogenetic classification of the land plants to accompany APG III. Botanical Journal of the Linnean Society 161:122-127.

Christenhusz MJM, Zhang XC, Schneider H (2011a). A linear sequence of extant families and genera oflycophytes and ferns. Phytotaxa 19:7-54.

Christenhusz MJM, Reveal JL, Farjon A, Gardner MF, Mill RR, Chase MW (2011b). A new classification and linear sequence of extant gymnosperms. Phytotaxa 19:55-70.

Chytrý M, Maskell LC, Pino J, Pysek P, Vila M, Font X, Smart SM (2008). Habitat invasions by alien plants: a quantitative comparison among Mediterranean, subcontinental and oceanic regions of Europe. Journal of AppliedEcology 45:448-458.

Chytry M, Pysek P, Wild J, Pino J, Maskell LC, Vila M (2009). European map of alien plant invasions based on the quantitative assessment across habitats. Diversity and Distributions 15:98-107.

Constan SD (2012). Ecologia de la especies invasora Ailanthus altissima (Mill.) Swingle. Bases para su control y erradicacion en Espacios Naturales Protegidos [Ecology of the invasive species Ailanthus altissima (Mill.) Swingle. Bases for their control and eradication in Protected Natural Spaces]. PhD thesis, Universitat d'Alacant. Alicante.

Costa JA, Neto C, Capelo J, Lousa M, Rivas-Martinez S (2011). A global view on the riparian forests with Salix neotricha and Populus alba in the Iberian Peninsula (Portugal and Spain). Plant Biosystems 145:553-569.

Crawley MJ, Harvey PH, Purvis A (1996). Comparative ecology of the native and alien floras of the British Isles. Philosophical Transactions of the Royal Society ofLondon 351:1251-1259.

Cronk JK, Fennessy MS (2001). Wetland Plants: Biology and Ecology. CRC Press/Lewis Publishers. Boca Raton, Florida, USA.

Daehler CC (2006). Invasibility of tropical islands: partitioning the influence of isolation and propagule pressure. Preslia 78:389-404.

DAISIE (2014). Delivering Alien Invasive Species Inventories for Europe. Retrieved 2017 January 20 from http://www.europe-aliens.org.

Ditomaso JM (2003). Aquatic and Riparian Weeds of the West. Collingdale, DIANE Publishing Company.

Domènech R, Vila M (2008). Response of the invader Cortaderia selloana and two coexisting natives to competition and water stress. Biological Invasions 10:903-912.

Ervin G, Smothers M, Holly C, Anderson C, Linville J (2006). Relative importance of wetland type versus anthropogenic activities in determiningsite invisibility. Biological Invasions 8:1425-1432.

Euro+Med (2006-onwards). Euro+Med PlantBase - the information resource for Euro-Mediterranean plant diversity. Retrieved 2016 September 20 from http://ww2.bgbm.org/EuroPlusMed.

Genovesi P (2007). Towards a European Strategy to halt biological invasions in inland waters. In: Biological Invaders in Inland Waters: Profiles, Distribution and Threats. Vol 2 (Gherardi F - Ed). Invanding NatureSpringer Series in Invasion Ecology (Drake J - Ed). University of Tennessee, Knoxville, TN, USA.

Gitay H, Finlayson CM,Davidson N (2011). A Framework for assessing the vulnerability of wetlands to climate change. Ramsar Convention Secretariat. Gland, Switzerland.

Gómez-Serrano MA, Mayoral O (2001). Elaboración de un estudio aplicado al control de plantas invasoras en la Comunidad Valenciana. Conselleria de Medi Ambient. Generalitat Valenciana. Valencia, Spain.

Gómez-Serrano MA, Mayoral O (2003). Caracterización de la flora naturalizada en un ambiente Mediterráneo [Characterization of the naturalized flora in a Mediterranean environment]. In: I Congreso Nacional sobre especies exóticas invasoras "EEI 2003”, Serie Técnica N.1.(ed. G.E.I.) 47 June2003, León, Spain 192-197.

Gritti ES, Smith B, Sykes T (2006). Vulnerability of Mediterranean Basin ecosystems to climate change and invasion by exotic plant species. Journal of Biogeography 33:145-157.

Hood WG, Naiman RJ (2000). Vulnerability of riparian zones to invasion by exotic vascular plants. Plant Ecology 148:105-114.

Hulme PE, Brundu G, Camarda I, Dalias P, Lambdon P, Lloret F, ... Vila M (2008). Assessing the risks to Mediterranean islands ecosystems from alien plant introductions. In: Plant invasions: human perception, ecological impacts and management. Tokarska-Guzik B (Ed). Backhuys Publishers, Leiden, The Netherlands pp 39-56.

Hussner A (2009). Growth and photosynthesis of four invasive aquatic plant species in Europe. Weed Research 49:506-515.

Hussner A (2012). Alien aquatic plant species in European countries. Weed Research 52:297-306.

Keller RP, Geist J, Jeschke JM, Kühn I (2011). Invasive species in Europe: ecology, status, and policy. Environmental Sciences Europe 23:23.

Keller RP, Perrings C (2011). International policy options for reducing the environmental impacts of invasive species. BioScience 61(12):10051012.

Laguna E, Ferrer PP, Collado F, Vizcaíno A (2009). Primera cita de Dactyloctenium aegyptium (L.) Willd. (Poaceae) en la Comunitat Valenciana [First record of Dactyloctenium aegyptium (L.) Willd. (Poaceae) in the Comunitat Valenciana].Studia Botanica28:175-178.

Leopold LB, Wolman MG, Miller JP (1964). Fluvial processes in geomorphology. Dover Publications, Inc, New York.

Lonsdale M (1999). Global patterns of plant invasions and the concept of invasibility. Ecology 80:1522-1536.

Lloret F, Médail F, Brundu G, Mus M, Hulme PE (2004). Local and regional abundance of exotic plant species on Mediterranean islands: are species traits important? Global Ecology and Biogeography 13:37-45.

Mayoral O, Donat-Torres MP, Jiménez MJ (2012). ¿Está desplazando Cortaderia selloana a Erianthus ravennae en los humedales de la Comunidad Valenciana? Consideraciones sobre sus tasas de germinación [Is Cortaderia selloana (Schult. \& Schult. F.) Asch. \& Graebn. displacing Erianthus ravennae (L.) Beauv. in the wetlands of the Valencian Community? Considerations on their germination rates]. $4^{\circ}$ Congreso Nacional sobre Especies Exóticas Invasoras (EEI 2012). (1011 September 2012, Pontevedra, Spain). Notas Científicas. Ed. G.E.I, León,Spain pp 117-119.

Meehl GA, Tebali C (2004). More intense, more frequent, and longer lastingheat waves in the 21st Century. Science 305 (5686):994997.

Miller C, Kettunen M, Shine C (2006). Scope options for EU action on invasive alien species (IAS). Final report for the European Commission. Institute for European Environmental Policy(IEEP), Brussels. 
326

Mittermeier RA, Robles Gil P, Hoffman M, Pilgrim J, Brooks T, Goettsch Mittermeier C, Lamoreux J, Da Fonseca GAB (2005). Hotspots revisited: earth's biologically richest and most endangered terrestrial ecoregions. University of Chicago Press, Chicago, USA.

Moragues E, Rita J (2005). Els vegetals introduits a les Illes Balears [Introduced plants in the Balearic Islands]. Documents tècnics de conservaciò, Ila època, núm. 11. Govern de les Illes Balears, Conselleria deMediAmbient, Palma.

Myers N, Mittermeier RA, Mittermeier CG, Da Fonseca GAB, Kent J (2000). Biodiversity hotspots for conservation priorities. Nature 403:853-858.

PignattiS (1982). Flora d'Italia 1-3.Edagricole. Bologna.

Pino J, Gassó N, Vila M, Sol D (2008). Regiones y hábitats más invadidos [Most invaded regions and habitats]. In: Vila M, Valladares F, Traveset A, Santamaría L, Castro P (Coord.) Invasiones Biológicas. Consejo Superior de Investigaciones Científicas (CSIC). Madrid.

Podda L, Fraga i Arguimbau P, Mayoral O, Mascia F, Bacchetta G (2010). Comparación de la flora exótica vascular en sistemas de islas continentales: Cerdeña (Italia) y Baleares (España) [Comparison of the vascular exotic flora in continental islands: Sardinia (Italy) and Balearic Islands(Spain)].Anales del Jardín Botánico de Madrid 67:157-176.

Podda L, Fraga i Arguimbau P, Mascia F, Mayoral O, Bacchetta G (2011). Comparison of the invasive alien flora in continental islands: Sardinia (Italy) and Balearic Islands (Spain). Rendiconti Lincei Science Fisiche e Naturali22:31-45.

PoddaL, LazzeriV, MasciaF, Mayoral O, Bacchetta G (2012). The checklist of the Sardinian exotic flora: an update. Notulae Botanicae Horti AgrobotaniciCluj-Napoca40:1421.

Puddu S, Podda L, Mayoral O, Delage A, Hugot L, Petit Y, Bacchetta G (2016). Comparative analysis of the alien vascular flora of Sardinia and Corsica. Notulae Botanicae Horti Agrobotanici Cluj-Napoca 44:337346.

Pysek P, Richardson DM, Rejmánek M, Webster GL, Williamson M, Kirschner J (2004). Alien plants in checklist and floras: towards better communication between taxonomist and ecologists. Taxon 53:131143.

Pysek P, Jarošík V, Pergl J, Moravcová L, Chytrý M, Kühn I (2014). Temperate trees and shrubs as global invaders: the relationship between invasiveness and native distribution depends on biological traits. Biological Invasions 16:577-589.

Raunkiaer C (1934). The life forms of plants and statistical plant geography. Univ Oxford. Oxford.

RAMSAR (1971). Convention on Wetlands of International Importance especially as Waterfowl Habitat. Ramsar (Iran), 2 February 1971. UN Treaty Series No. 14583. As amended by the Paris Protocol, 3 December 1982, and Regina Amendments, 28 May 1987.

Richardson DM (1998). Forestry Trees as Invasive Aliens. Conservation Biology 12:18-26.

Richardson DM, Pysek P, Carlton JT (2011). A compendium of essential concepts and terminology in biological invasions. In: Fifty years of invasion ecology: the legacy of Charles Elton (ed. DM Richardson) Oxford, UK: Blackwell Publishing pp 409-420.

Richardson DM, Pysek P, Rejmánek M, Barbour MG, Panetta FD, West
CJ (2000). Naturalization and invasion of alien plants: concepts and definitions. Diversity and Distributions 6:93-107.

Richardson M, Hui C, Nuñez MA, Pauchard A (2014). Tree invasions: patterns, processes, challenges and opportunities. Biological invasions 16:473-481.

Rivas-Martínez S (2007). Mapa de series, geoseries y geopermaseries de vegetación de España [Map of series, geoseries and geopermaseries of vegetation in Spain]. Itinera Geobotanica 17:5-436.

Sala OE, Chapin FS, Armesto JJ, Berlow E, Bloomfield J, Dirzo R, ... Wall $\mathrm{DH}$ (2000). Global biodiversity scenarios for the year 2100 . Science 287:1770-1774.

Sanz-Elorza M, Dana ED, Sobrino E (2004). Atlas de las plantas alóctonas invasoras en España [Atlas of invasive alien plants in Spain]. Ministerio deMedio Ambiente, Madrid.

Sanz-Elorza M, Guillot D, Deltoro V (2011). La flora alóctona de la Comunidad Valenciana [The non-native flora of the Valencian Community]. Botanica Complutensis 35:97-130.

Sarris D, Koutsias N (2014). Ecological adaptations of plants to drought influencing the recent fire regime in the Mediterranean. Agricultural and Forest Meteorology 184:158-169.

SENB-CIEF (2011). Identificación de la especie arbórea invasora Diospyros lotus [Identification of the invasive tree species Diospyros lotus]. Servicio de Espacios Naturales y Biodiversidad (SENB) - Centro para la Investigación y Experimentación Forestal (CIEF), Generalitat Valenciana. Valencia. Retrieved 2017 January 02 from http://bdb.cma.gva.es/webdoc/documento.ashx?id=168460.

Smith VH, Tilman GD, Nekola JC (1999). Nutrient enrichment: impacts of excess nutrient inputs on fresh- water, marine and terrestrial ecosystems. Environmental Pollution 100:179-196.

Stevens PF (2001-onwards). Angiosperm phylogeny website. Retrieved 2016 September 20 from 9http://www.mobot.org/MOBOT/ research/APweb/.

Strayer DL (2010). Alien species in fresh waters: ecological effects, interaction with other stressors, and prospects for the future. Freshwater Biology 55:152-174.

The Plant List (2013). Version 1. Retrieved 2016 September 20 from http://www.theplantlist.org/.

Vila M, Basnou C, Pysek PM, Josefsson M, Genovesi P, Gollasch S, ... DAISIE partners (2009). How well do we understand the impacts of alien species on ecosystem services? A pan-European, cross-taxa assessment. Frontiers in Ecology and the Environment 8:135-144.

Vila M, Muñoz I (1999). Patterns and correlates of exotic and endemic plant taxa in the Balearic Islands. Ecologia Mediterranea 25:153-161.

Vila M, Valladares F, Traveset A, Santamaría L, Castro P (2008). Invasiones biológicas [Biological invasions]. Consejo Superior de Investigaciones Cientificas, Madrid.

Weber E (2003). Invasive plant species of the world. A reference guide to environmental weeds. CABI publishing, Wallingford, UK.

Wilby NJ (2007). Managing invasive aquatic plants: problems and prospects. Aquatic conservation: Marine and Freshwater Ecosystems 17:659-665. 